\title{
Impact of temperature and rainfall on symptom expression of barley yellow mosaic in Poland and preliminary assessment of the reaction of winter barley cultivars to the virus
}

\author{
Wpływ warunków pogodowych na występowanie wirusa \\ żółtej mozaiki jęczmienia (Barley yellow mosaic virus, BaYMV) w Polsce \\ oraz ocena podatności odmian jęczmienia ozimego na zakażenie
}

\author{
Małgorzata Jeżewska
}

\section{Summary}

Barley yellow mosaic is a serious winter barley disease caused by two viruses: Barley yellow mosaic virus (BaYMV) and Barley mild mosaic virus (BaMMV). The viruses are called "soil-borne" as they are transmitted by a root-inhabiting fungal-like plasmodiophorid vector, Polymyxa graminis Led. The analysis of the disease incidence in 2008 (the highest) and 2011 (the lowest) revealed that the disease symptom expression was significantly influenced by the weather conditions, mainly temperature and rainfall. The reaction of 20 winter barley cultivars on the BaYMV infection was investigated. The first results indicated a good level of resistance within the tested plant materials.

Key words: winter barley, barley yellow mosaic, soil-borne viruses, resistance

\begin{abstract}
Streszczenie
Żółta mozaika jęczmienia (ŻMJ), wywoływana przez wirusy: żółtej mozaiki jęczmienia (Barley yellow mosaic virus, BaYMV) ¡ łagodnej mozaiki jęczmienia (Barley mild mosaic virus, BaMMV) należy do grupy chorób tzw. odglebowych, gdyż wektorem jej sprawców jest występujący w glebie pierwotniak, Polymyxa graminis Led. ŻMJ zagraża wyłącznie ozimym formom jęczmienia. Na podstawie porównania nasilenia występowania choroby w latach 2008 (najwyższe) i 2011 (najniższe) wykazano ścisły związek pomiędzy przebiegiem warunków pogodowych, głównie temperatury i opadów, a ujawnianiem się objawów chorobowych. Przebadano reakcje 20 odmian jęczmienia ozimego z Listy Odmian wpisanych do krajowego rejestru Centralnego Ośrodka Badania Odmian Roślin Uprawnych (COBORU) na porażenie przez BaYMV. Wstępnie stwierdzono niską podatność analizowanych materiałów.
\end{abstract}

Słowa kluczowe: jęczmień ozimy, żółta mozaika jęczmienia, wirusy odglebowe, odporność

Instytut Ochrony Roślin - Państwowy Instytut Badawczy

Zakład Wirusologii i Bakteriologii

Władysława Węgorka 20, 60-318 Poznań

m.jezewska@iorpib.poznan.pl 


\section{Wstęp / Introduction}

Żółta mozaika jęczmienia (ŻMJ), wywoływana przez wirusy: żółtej mozaiki jęczmienia (Barley yellow mosaic virus, BaYMV) i łagodnej mozaiki jęczmienia (Barley mild mosaic virus, BaMMV), występująca wyłącznie na jęczmieniu ozimym, należy do grupy chorób tzw. odglebowych, gdyż wektorem jej sprawców jest występujący w glebie pierwotniak Polymyxa graminis Led. (Adams 1996). BaYMV został po raz pierwszy opisany w Japonii (Usugi i Saito 1976). W Europie wirus ten został stwierdzony pod koniec lat 70. XX wieku (Huth i Lesemann 1978), a w następnych latach szybko rozprzestrzenił się. W Polsce choroba została wykryta po raz pierwszy w 2008 roku na Dolnym Śląsku (Jeżewska i Trzmiel 2009). W latach następnych nowe ogniska wirozy zidentyfikowano również $w$ innych rejonach kraju. Objawy żółtej mozaiki jęczmienia są mało specyficzne. Pojawiają się wczesną wiosną. Na liściach widoczne są żółtawe przebarwienia, czasami drobne plamki i smugi, a nawet nekrozy. Następuje też zahamowanie wzrostu roślin. Badania wykazały, że głównym sprawcą objawów chorobowych jest BaYMV, a nasilenie pojawiania się symptomów podlega znacznym wahaniom (Jeżewska i wsp. 2010).

Szkodliwość ŻMJ dla podatnych odmian jęczmienia ozimego jest potencjalnie znacząca, a straty plonu wynoszą kilkadziesiąt procent (Plumb i wsp. 1986; Huth 1989). W rejonach występowania wirusów ŻMJ zalecana jest uprawa odmian odpornych i tolerancyjnych, jako jedyna metoda uniknięcia bezpośrednich strat plonu oraz ograniczania rozprzestrzeniania się patogenów. Badania nad odpornością odmian jęczmienia na BaYMV i BaMMV były prowadzone w wielu krajach, a szczególnie w Japonii i w Niemczech (Kühne 2009).

Celem pracy było zbadanie wpływu czynników pogodowych, temperatury i opadów, na występowanie ŻMJ na jęczmieniu ozimym w rejonach potwierdzonej obecności jej sprawców, jak również ocena reakcji na zakażenie przez BaYMV wybranych odmian jęczmienia ozimego z Listy Odmian Krajowego Rejestru Centralnego Ośrodka Oceny Odmian Roślin Uprawnych (COBORU).

\section{Materiały i metody / Materials and methods}

Standardową diagnostykę BaYMV wykonywano testem DAS-ELISA $\mathrm{z}$ wykorzystaniem komercyjnego zestawu immunoglobuliny i koniugatu produkcji firmy Loewe (Niemcy). Monitoring występowania sprawców ŻMJ na jęczmieniu ozimym prowadzono od 2008 roku. W 2011 roku zrezygnowano z wykrywania BaMMV, ze względu na ograniczoną szkodliwość tego wirusa, zaobserwowaną podczas badań w trzech poprzednich latach.

\section{Wpływ warunków pogodowych na występowanie objawów ŻMJ}

Porównywano przebieg średnich temperatur oraz sum opadów występujących $\mathrm{w}$ okresie od października do kwietnia, w latach 2007/2008 i 2010/2011, czyli w sezonach maksymalnego i minimalnego pojawu ŻMJ. Źródłem danych meteorologicznych był Biuletyn Państwowej
Służby Hydrologiczno-Meteorologicznej. Głównymi rejonami występowania ŻMJ są województwa: dolnośląskie, lubelskie, mazowieckie, śląskie i wielkopolskie, dlatego analizowano średnie wartości temperatur i sum opadów dla tych rejonów.

\section{Ocena reakcji odmian jęczmienia ozimego na BaYMV}

$\mathrm{W}$ doświadczeniu dotyczącym oceny reakcji odmian jęczmienia na mechaniczną inokulację użyto niemiecki izolat BaYMV GlenTorf Gruppel (BaYMV-De), otrzymany $\mathrm{z}$ Bundesanstalt für Züchtungforschung an Kulturpflanzen (BAZ) w Quedlinburgu (Niemcy). Nasiona 20 odmian jęczmienia ozimego: Antonella, Bażant, Bursztyn, Epoque, Fridericus, Henriette, Holmes, Karakan, Lomerit, Matilda, Maybrit, Meridian, Merlot, Nickela, Rosita, Scarpia, Souleyka, Titus, Traminer i Wendy uzyskano bezpośrednio od hodowców lub ich przedstawicieli (w przypadku odmian zagranicznych). Doświadczenie przeprowadzono $\mathrm{w}$ komorze fitotronowej, przy standardowym oświetleniu i w temperaturze $15^{\circ} \mathrm{C}$ (dzień) oraz $10^{\circ} \mathrm{C}$ (noc). Z każdej odmiany jęczmienia inokulowano mechanicznie 32 rośliny izolatem BaYMV w fazie 3 liści, a następnie obserwowano rozwój objawów chorobowych. Po 7-8 tygodniach od inokulacji oceniano występowanie BaYMV w inokulowanych roślinach jęczmienia testem ELISA. Doświadczenie wykonano dwukrotnie.

\section{Wyniki i dyskusja / Results and discussion}

\section{Wpływ warunków pogodowych na występowanie objawów ŻMJ}

Monitoring występowania sprawców ŻMJ na jęczmieniu ozimym prowadzono od 2008 roku. W 2011 roku zrezygnowano $\mathrm{z}$ wykrywania BaMMV, ze względu na ograniczoną szkodliwość tego wirusa, zaobserwowaną podczas badan $w$ trzech poprzednich latach i skupiono się wyłącznie na wykrywaniu BaYMV.

W rejonach występowania ŻMJ w 2011 roku stwierdzono znaczące ograniczenie pojawiania się objawów chorobowych oraz obniżenie wykrywalności sprawcy. Uzyskane wyniki różniły się szczególnie w zestawieniu z wynikami zebranymi w roku 2008 (tab. 1).

Tabela 1. Porównanie wykrywania wirusa żółtej mozaiki jęczmienia (BaYMV) w latach 2008 i 2011

Table 1. Comparison of the detection of Barley yellow mosaic virus (BaYMV) in the years 2008 and 2011

\begin{tabular}{l|c|c}
\hline \multicolumn{1}{c|}{$\begin{array}{l}\text { Wykrywanie BaYMV } \\
\text { Detection of BaYMV }\end{array}$} & 2008 & 2011 \\
\hline $\begin{array}{l}\text { Ogólna liczba prób pobranych do analiz } \\
\text { jako podejrzane o porażenia } \\
\text { Total number of analysed samples }\end{array}$ & 352 & 212 \\
$\begin{array}{l}\text { \% wykrywania wirusów w próbach } \\
\text { \% of sampled found infected with } \\
\text { BaYMV }\end{array}$ & $34,6^{*}$ & 24,1 \\
\hline
\end{tabular}

*W województwie dolnośląskim \% wykrywania wyniósł 79,2 in Lower Silesia the percentage of virus detection was 79,2 
Przeanalizowano ekspresję objawów w zależności od panujących temperatur oraz sumy opadów w okresach od października do marca, w sezonach 2007/2008 i 2010/2011. Graficzne porównanie średnich wartości temperatur i sum opadów zilustrowano na wykresach (rys. 1, 2). Analiza średnich temperatur jesiennych wskazuje na ich łagodny przebieg w 2007 roku oraz gwałtowny spadek w grudniu 2010 roku, w którym nastąpiło obniżenie temperatury o $4,9^{\circ} \mathrm{C}$ w stosunku do średniej wieloletniej. Takie gwałtowne załamanie temperatur w roku 2010 spowodowało zahamowanie procesów biologicznych, w tym także rozwoju infekcji wirusowych. Warunki hydrologiczne również kształtowały się, z punktu widzenia rozwoju wiroz, stosunkowo korzystnie jesienią 2007 roku, natomiast susza w październiku 2010 roku (tylko 15\% normy wieloletniej) całkowicie zahamowała przemieszczanie wektora i zakażanie roślin. Wprawdzie już pod koniec listopada 2010 r. nastapiły obfite opady, ale były one połączone $\mathrm{z}$ silnym obniżeniem temperatur, hamującym rozwój roślin i porażeń wirusowych. Miało miejsce też istotne nawodnienie pól w okresie wiosennym, tzn. w marcu i kwietniu, na co wskazują różnice sum opadów w latach 2008 i 2011. W marcu i kwietniu 2008 roku sumy opadów wyniosły - 46,8 i 57,2 mm, stanowiąc odpowiednio - 147 i 152\% normy. Przeciwną sytuację odnotowano w 2011 roku, kiedy sumy opadów wyniosły - 22,6 i $25,3 \mathrm{~mm}$, stanowiąc odpowiednio - 66 i $63 \%$ normy.

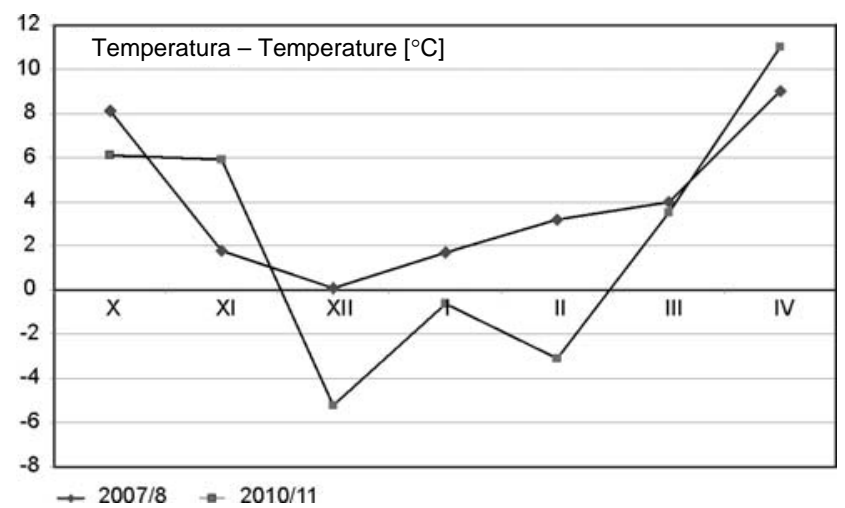

Rys. 1. Porównanie przebiegu średnich temperatur na przełomie lat 2007/2008 oraz 2010/2011 w głównych rejonach występowania chorób wirusowych zbóż (województwa: dolnoślaskie, lubelskie, mazowieckie, śląskie i wielkopolskie); w nawiasach podano odchylenia od średnich temperatur wieloletnich

Fig. 1. The course of mean temperature in the years 2007/2008 and 2010/2011 in principal regions of cereal virus occurrence in Poland (Lower Silesia, Lubelskie, Mazovia, Upper Silesia and Great Poland); in parenthesis the deviation of multi year mean is given

Panujące temperatury i występujące opady odgrywają znaczącą rolę w rozwoju porażeń zarówno ze względu na zdolność przemieszczania się zarodników wektora, jak i ze względu na namnażanie i transport wirusów w roślinie gospodarzu (Adams i Swaby 1988; Adams 2002). Nie mamy wpływu na warunki pogodowe, dlatego niezbędne jest zabezpieczanie się przed porażeniami poprzez uprawę odmian odpornych i tolerancyjnych.

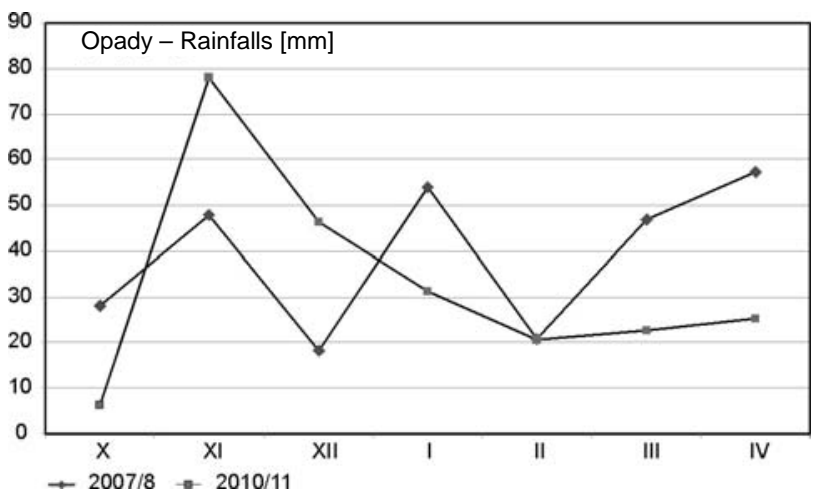

Rys. 2. Porównanie sum opadów na przełomie lat $2007 / 2008$ oraz 2010/2011 w głównych rejonach występowania chorób wirusowych zbóż (województwa: dolnośląskie, lubelskie, mazowieckie, śląskie i wielkopolskie); w nawiasach podano \% normy dla średniej wieloletniej

Fig. 2. Rainfalls in the years $2007 / 2008$ and $2010 / 2011 \mathrm{i}$ principal regions of cereal virus occurrence (Lower Silesia, Lubelskie, Mazovia, Silesia and Great Poland); in parenthesis the percentage of multi year norm is given

\section{Ocena reakcji odmian jęczmienia ozimego na BaYMV}

Ocenę reakcji odmian jęczmienia ozimego na inokulację mechaniczną niemieckim izolatem BaYMV przedstawiono w tabeli 2 . Średni procent skutecznych zakażeń 64 roślin z każdej odmiany jęczmienia potraktowano jako wskaźnik podatności danej odmiany na BaYMV. Najwyższy udział roślin porażonych odnotowano dla odmiany Titus $(14,4 \%)$, a nieco mniejszy $(11,2 \%)$ dla

Tabela 2. Reakcja odmian jęczmienia ozimego na zakażenie mechaniczne wirusem żółtej mozaiki jęczmienia, BaYMV (w obu doświadczeniach inokulowano po 32 rośliny z każdej odmiany)

Table 2. Reaction of winter barley cultivars on the mechanical inoculation with Barley yellow mosaic virus, BaYMV (in both experiments 32 plants of each cultivar were inoculated)

\begin{tabular}{l|c|c|c}
\hline \multirow{2}{*}{$\begin{array}{c}\text { Odmiana } \\
\text { Cultivar }\end{array}$} & $\begin{array}{c}\text { Liczba roślin porażonych } \\
\text { wg testu ELISA } \\
\text { Number of infected plants } \\
\text { by ELISA test }\end{array}$ & $\begin{array}{c}\text { Średni } \\
\% \text { porażeń } \\
\text { Average } \\
\text { percentage } \\
\text { of infected } \\
\text { plants }\end{array}$ \\
\cline { 2 - 3 } \multicolumn{1}{c|}{$\begin{array}{c}\text { doświadczenie I } \\
\text { experiment I }\end{array}$} & $\begin{array}{c}\text { doświadczenie II } \\
\text { experiment II }\end{array}$ & 4 \\
\hline Antonella & 2 & 3 & 6,3 \\
\hline Bażant & 3 & 1 & 6,3 \\
\hline Bursztyn & 1 & 1 & 1,6 \\
\hline Epoque & 1 & 0 & 3,1 \\
\hline Fridericus & 1 & 1 & 1,6 \\
\hline Henriette & 0 & 0 & 0 \\
\hline Holmes & 3 & 0 & 4,8 \\
\hline
\end{tabular}




\begin{tabular}{l|l|l|c}
\hline \multicolumn{1}{c|}{1} & 2 & 3 & 4 \\
\hline Karakan & 1 & 0 & 1,6 \\
\hline Lomerit & 1 & 0 & 1,6 \\
\hline Matilda & 4 & 1 & 8,0 \\
\hline Maybrit & 0 & 0 & 0 \\
\hline Meridian & 1 & 5 & 9,6 \\
\hline Merlot & 5 & 0 & 8,0 \\
\hline Nickela & 2 & 0 & 3,1 \\
\hline Rosita & 1 & 4 & 8,0 \\
\hline Scarpia & 0 & 1 & 1,6 \\
\hline Souleyka & 0 & 0 & 0 \\
\hline Titus & 1 & 8 & 14,4 \\
\hline Traminer & 0 & 7 & 11,2 \\
\hline Wendy & 0 & 3 & 4,8 \\
\hline
\end{tabular}

mentu w warunkach polowych, przy założeniu naturalnej infekcji z udziałem wektora oraz polskiego izolatu wirusa.

Stosowanie odmian odpornych jest jedynym sposobem zabezpieczenia upraw jęczmienia ozimego przed wirusami ŻMJ, dlatego prowadzono rozległe badania nad tym zagadnieniem, zarówno $\mathrm{w}$ aspekcie poszukiwania odmian odpornych, jak i wyjaśnienia mechanizmów tej odporności (Friedt i wsp. 1989; Götz i Friedt 1993; Friedt i Ordon 1995; Graner i wsp. 1999). Biorąc pod uwagę dynamikę zmienności biologicznej, konieczna jest jednak weryfikacja istniejących danych, $\mathrm{z}$ uwzględnieniem polskiego izolatu BaYMV oraz warunków środowiskowych.

\section{Wnioski / Conclusions}

1. Wykazano znaczący wpływ temperatury i opadów, na występowanie roślin jęczmienia ozimego porażonych przez wirus żółtej mozaiki jęczmienia.

odmiany Traminer. W pozostałych przypadkach procent porażeń nie przekraczał 10, a 3 odmiany: Henriette, Maybrit i Souleyka w ogóle nie były porażone. Podsumowując, można stwierdzić, że na podstawie wstępnych danych wszystkie badane odmiany wykazały niską podatność na zakażenie BaYMV. Jednak dla wiarygodnej oceny odporności niezbędne jest powtórzenie ekspery-

2. Wstępne wyniki badań reakcji 20 odmian jęczmienia ozimego z krajowego rejestru odmian COBORU na zakażenie przez wirus żółtej mozaiki jęczmienia (BaYMV) wskazują na ich niską podatność na ten wirus.

\section{Literatura / References}

Adams M.J. 1996. Barley yellow mosaic bymovirus. p. 167-170. In: "Viruses of Plants. Descriptions and Lists from the VIDE database" (A.A. Brunt, K. Crabtree, M.J. Dallwitz, A.J. Gibbs, L. Watson, eds.). CAB International, Wallingford, UK, 1484 pp.

Adams M.J. 2002. The mosaic viruses of winter barley: problems and prospects. The BCPC Conference - Pests and Diseases 3B-I: $105-112$.

Adams M.J., Swaby A.G. 1988. Factors affecting the production and motility of zoospores of Polymyxa graminis and their transmission of barley yellow mosaic virus (BaYMV). Ann. Appl. Biol. 112: 69-78.

Friedt W., Götz R., Kaiser R., Foroughi-Wehr B. 1989. Present state and prospects of breeding for resistance or immunity to barley yellow mosaic virus. Bull. OEPP/EPPO Bull. 19: 563-571.

Friedt W., Ordon F. 1995. Breeding for resistance to bymoviruses in Poaceae with special consideration for the barley yellow mosaic virus complex. Agronomie 15: 453-458.

Götz R., Friedt W. 1993. Resistance to the barley yellow mosaic virus complex - differential genotypic reactions and genetics of BaMMV - resistance of barley (Hordeum vulgare L.). Plant Breeding 111: 125-131.

Graner A., Streng S., Kellermann A., Proeseler G., Schiemann A., Peterka H., Ordon F. 1999. Molecular mapping of genes conferring resistance to soil-borne viruses in barley - an approach to promote understanding of host-pathogen interactions. J. Plant Dis. Prot. 106 (4): 405-410.

Huth W. 1989. Management of yellow mosaic - inducing viruses on barley by selection of resistant cultivars. Bull. OEPP/EPPO Bull. 19: 547-553.

Huth W., Lesemann D.E. 1978. Eine für die Bundesrepublik neue Virose an Wintergerste. Nachrichtenbl. Dt. Pflanzenschitzd. 30: $184-185$.

Jeżewska M., Cajza M., Buchowska-Ruszkowska M. 2010. Monitoring i diagnostyka molekularna wirusów zbóż. s. 157-180. W: „Ograniczanie strat w plonach roślin uprawnych z zachowaniem bezpieczeństwa żywności” (D. Sosnowska, red.). Inst. Ochr. Roślin - PIB, 284 ss.

Jeżewska M., Trzmiel K. 2009. First report of Barley yellow mosaic virus infecting barley in Poland. Plant Pathol. 58, p. 784.

Kühne T. 2009. Soil-borne viruses affecting cereals - known for long but still a threat. Virus Res. 141: 174-183.

Plumb R.T., Lennon E.A., Gutteridge R.A.Q. 1986. The effects of infection by barley yellow mosaic virus on the yield and components of yield of barley. Plant Pathol. 35: 314-318.

Usugi T., Saito Y. 1976. Purification and serological properties of Barley yellow mosaic virus and Wheat yellow mosaic virus. Ann. Phytopathol. Soc. Jpn. 42: 12-20. 